\title{
Putting the Power of Transparency in Context: Information's Role in Reducing Corruption in Uganda's Education Sector \\ By Paul Hubbard
}

\begin{abstract}
One of the popular stories told (and taught) in development circles is how corruption was slashed in Uganda simply by publishing the amount of monthly grants to schools. This paper takes a deeper look at the facts behind the Uganda story and finds that while information did indeed play a critical role, the story is much more complicated than we have been led to believe. A dramatic drop did occur in the percentage of funds being diverted from Uganda's capitation grant. But to attribute this leakage solely to the monthly release of grant data by the government risks ignoring the major funding in which this transparency campaign was imbedded.
\end{abstract}

The Center for Global Development is an independent think tank that works to reduce global poverty and inequality through rigorous research and active engagement with the policy community. Use and dissemination of this Working Paper is encouraged, however reproduced copies may not be used for commercial purposes. Further usage is permitted under the terms of the Creative Commons License. The views expressed in this paper are those of the author and should not be attributed to the directors or funders of the Center for Global Development. 


\title{
Putting the Power of Transparency in Context: Information's Role in Reducing Corruption in Uganda's Education Sector
}

\author{
Paul Hubbard ${ }^{1}$
}

\footnotetext{
${ }^{1}$ With particular thanks to Dr Dennis De Tray for guiding the development of this paper and to the Center for Global Development for giving me a place to conduct my research. Also thanks to Selvin Akkus for aiding my understanding of the statistics involved, as well as to Rick Snell and Paolo de Renzio for their comments on early drafts. Mistakes and shortcomings are mine.
} 


\section{Foreword}

The development world is full of conventional wisdom. Repetition turns back of the napkin estimates into ingrained facts. Case studies are compressed into paragraphs, and research is presented shorn of its assumptions. The danger in all this is that we pursue development policies based on what sounds true, what we want to believe, rather than on the evidence.

One of the popular stories told (and taught) in development circles is how corruption was slashed in Uganda simply by publishing the amount of monthly grants to schools. I have myself referred many times to this story as an example of an apparently simple, institutionally undemanding and practical way of fighting corruption. I have also frequently wondered aloud why the Uganda example has not found its way into every government's fight against corruption. Paul Hubbard's short paper helps answer this puzzle. It sets about sifting fact from hyperbole and headline simplification, and finds that while information did indeed play a critical role in Uganda, the story is much more complicated that we may have been led to believe.

The main message of Paul's careful deconstruction of the Uganda example is not that information doesn't matter in the fight against corruption. Quite the contrary, information, from basic statistics to good research, played an essential role in reforming Uganda's primary education system, and holding in check leakages in the face of a massive increase in education funding. But Paul's research also underscores on an old truism: if it looks too good to be true, it probably is.

Dennis de Tray

Vice President, Special Initiatives

Center for Global Development

December, 2007 


\section{Putting the Power of Transparency in Context: Information's role in reducing corruption in Uganda's education sector}

The promotion of transparency policies as anti-corruption tools is popular based on the intuitive logic that secrecy breeds corruption and sunlight is the best disinfectant. But the idea that information disclosure policies actually have strong anti-corruption effects in developing countries is supported by little systematic evidence. One current example within development circles comes from Uganda. In his recent book The Bottom Billion, economist Paul Collier portrays this popular transparency case study as a promising example of bottom-up scrutiny:

"Each time the Ministry of Finance released money it informed the local media, and it also sent a poster to each school setting out what it should be getting. ... Now, instead of only 20 percent getting through to schools, 90 percent was getting through. In state-of-the-art statistical research that analyzed this experiment in detail, [Ritva] Reinikka and her colleague Jakob Svensson were able to demonstrate that the media had been decisive - in this case reports in newspapers. So scrutiny turned 20 percent into 90 percent - more effective than doubling aid and doubling it again.,"

But it is a mistake to attribute the entire reduction in corruption to a single publication policy. Reinikka and Svennson's research focuses on a small but significant element information provided through newspapers to local schools. But their research is best understood in terms of concurrent reforms in Uganda's education and fiscal systems. This paper examines a number of other policies and reforms that help explain the reported decline in corruption to Ugandan education in the 1990s.

Policy makers should take a nuanced view of the available evidence. For example, while the proportion of funds diverted did decline spectacularly, the real value of funds actually diverted fell by a modest $12 \%$ over six years. There are also suggestive reports that the efficacy of the information campaign has declined over time. The Uganda case study does provide good evidence that information plays a significant role in the political economy of corruption, but a close reading warns us not to overestimate the result.

\section{Initial Conditions - Primary education in Uganda 1991-1995}

The management of local primary schools was chaotic in early 1990s. The number of primary schools had doubled the decade before. They were run by local parent teacher association (PTA) and the staff, few of whom had management skills. ${ }^{3}$ Parents provided more than half the primary school budget. ${ }^{4}$ The rest was funded by the government in two major streams. The Ministry of Education paid a share of teacher salaries. The Ministry of Local Government provided money for school supplies. The amount for

Collier (2007), page 150

USAID (1991)

Ablo and Reinikka (1998), page 12 
school supplies was based on the student enrollment and is therefore called a capitation grant. $^{5}$

Initially the capitation funding should have constituted almost half the government contribution to primary education. But inflation eroded two thirds of its real value between 1991 and 1995. Meanwhile, the government almost doubled teacher salaries in real terms, and parental contributions also increased. Had it been received in full, the capitation would have been $12 \%$ of government funding to primary schools in $1995 .{ }^{6}$

The central government of Uganda paid the capitation money to district governments in a 'block grant'. This bundled together twenty-four separate grants into a single amount that was transferred to a district government. ${ }^{7}$ Although the district was supposed to pass the capitation funds on to primary schools within the district, the block grant arrangement did not require that the funds be accounted for. ${ }^{8}$ In principle the capitation grant should have been provided by the District Education Officer to each school's head teacher, who should then have handed it over to the school.

Unfortunately, the entire system was chaotic. Lines of communication between the local school, the district officials and the central government were poor. The Ministry of Education's official statistics did not match actual local school enrollment. ${ }^{9}$ In 1991 USAID noted that "[m]anagement of the educational system at the school and district levels is abysmally weak. Systems for record-keeping and accounting are inadequate, leading to misallocation of funds, salary payments to 'ghost' teachers and a general lack of fiscal accountability."10

\section{The 1996 and 2002 Public Expenditure Tracking Surveys}

It is not surprising therefore that a World Bank survey in 1996 revealed that most of the capitation money that was paid out by the central government disappeared before it reached schools. They surveyed 250 randomly selected schools in 19 districts around the country and looked at school records for the last five years. Despite the confusion within school administration, they were amazed to find that the financial records at the local level were "relatively comprehensive," perhaps because parents had provided the bulk of school funding and therefore demanded accountability. ${ }^{11}$

Researchers came up with a measure of funding 'leakage' - they divided the amount of capitation actually received by the school by the amount that they should have received. The results of this analysis showed that from 1991-1995, only $12.6 \%$ of the centrally allocated funds ever reached the school. The share had been increasing; by 1995 about $21.9 \%$ of the capitation funds reached schools. Most schools received no share

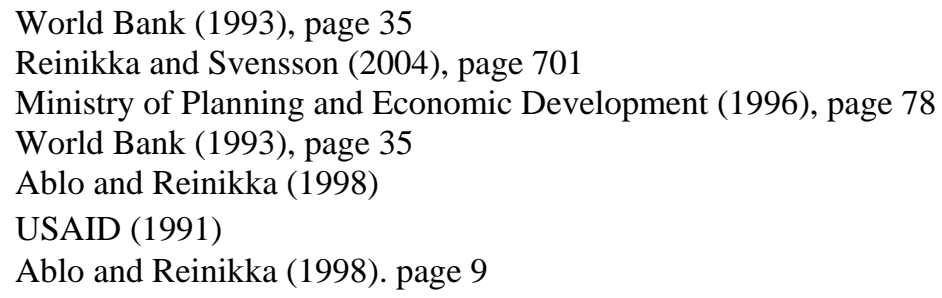


whatsoever of their capitation entitlement. Parents and teachers were largely unaware that the capitation grant existed. ${ }^{12}$

Four years later, in 1999, the Ugandan Ministry of Education and Sports commissioned a review which found that the median school now received $90 \%$ of the capitation entitlement. ${ }^{13}$ These 'dramatic improvements' were feted in the World Bank's 2000-01 Development Report and attributed mostly to the increased information flow. ${ }^{14}$

To test the hypothesis that the results were linked to access to information, Reinikka and Svensson proposed a follow up for a repeat Public Expenditure Tracking Survey. ${ }^{15}$ This was conducted in 2002. This survey revisited the schools originally surveyed in 1996, collected financial information based on the 2001 school year. To test the information hypothesis, additional data on schools' access to newspapers, distance from the nearest newspaper outlet ${ }^{16}$ and specific knowledge of the head teacher was also collected in the new survey.

The survey confirmed that schools were now receiving a much greater share of their entitlements than they did in 1995 . All schools now received some capitation; both the mean and median of share received was close to $80 \% .{ }^{17}$ Although this was less than the findings of the education ministry two years earlier, researchers were satisfied that leakage had dropped tremendously.

The new survey showed that schools with access to newspapers now received an $8.68 \%$ greater share of their entitlement than schools that did not have access to newspapers. Because schools with access to newspapers had actually received less money in 1995 than schools without, the difference in improvement between schools was slightly higher. ${ }^{18}$ These results were statistically significant at the $5 \%$ level and held when controlled for income. ${ }^{19}$

These improvements were also compared with the period from 1991-1995, before any of the information campaigns had taken place. In this earlier period, there had been a modest improvement in leakage, but the difference in improvement was not correlated with newspaper access - schools with newspaper access actually improved less. Only when information was provided in newspapers as part of the information campaign does the variation appear, supporting the information hypothesis.

\footnotetext{
12 Reinikka and Svensson (2004), pages 683, 687

Reinikka and Svensson (2001)

World Bank (2001)

Reinikka and Svensson (2001b)

Newspaper access provided good variation given the low rate of newspaper penetration in Uganda, about 2.67 daily newspaper per 1,000 people in 2000 , according to the World Development Indiciators.

$17 \quad$ Reinikka and Svensson (2006), page 27

18 The difference in improvement was 13.8\%

19 Reinikka and Svensson (2006), page 29
} 
Based on sophisticated statistical analysis, Reinikka and Svensson concluded that information "is a powerful deterrent to the diversion of grant funds at a local level."20 They discovered relationships between the school's distance to the nearest newspaper outlet and the head teacher's information about the grant program. They then used this distance from a newspaper to predict the change in grant entitlement, based on the head teacher's specific knowledge of grant entitlement and release date. They found that a "strong (reduced form) relationship exists between distance to the nearest newspaper outlet and reduction in grant fund diversion after the newspaper campaign began.”,1 Reinikka and Svensson never claimed that information was the only factor in explaining this apparent decrease in leakage. To properly evaluate the power of information in Uganda, it is necessary to pay close attention to all the reforms that took place in Uganda between 1995 and 2001.

\section{Uganda's finance, education and information reforms}

In the mid-1990s, Uganda was undergoing constitutional reform in order to decentralize power from Kampala to the districts. This involved changes to the manner in which central funds were allocated to the districts.

The miserable survey results had demonstrated to the Government of Uganda the extent to which funds were diverted or stolen within districts. The prior system of block grants which delivered funds as a lump sum without accountability was replaced in favor of conditional grants that were intended to serve as a check on district officials. ${ }^{22}$ By 2001 the central government had changed its methods, to pay the 22 separate conditional grants, including the capitation grant, into separate district bank accounts. ${ }^{23}$

The publication of monthly disbursements figures, firstly for the education capitation grant, and then for all grants, was introduced to place pressure on the districts to deliver the services for which they had received funds. This was mandated in the Local Governments Act of 1997. These figures continue to be published, and appear sporadically on the Ministry of Finance website. ${ }^{24}$

Education reform was also a major political issue in this period. A prominent plank of President Musevini's 1996 election campaign was the introduction of Universal Primary Education (UPE). After his re-election, he announced that from the 1997 school year, tuition would be free for up to four children per family. Compulsory parental contributions which had previously made up such a large part of the school budget were abolished. $^{25}$

UPE became widely known and wildly popular throughout Uganda. At the start of 1997 an additional 2.6 million pupils registered for school. This almost doubled the total

\footnotetext{
$20 \quad$ Reinikka and Svensson (2006), page 1

$21 \quad$ Reinikka and Svensson (2006), page 21

22 Ministry of Planning and Economic Development (1996), page 78, 120

23 Bevan (2001)

24 http://www.finance.go.ug/funding_wage2.php

25 Stasavage (2005)
} 
enrollment. ${ }^{26}$ Parents across Uganda were clearly aware of the new education policy, and were aware that the government would pay.

The introduction of UPE in the 1997 significantly changed the structure of school financing. Compulsory parental contributions had previously been a mainstay of school funding, but were abolished by UPE. Students whose parents could not afford the fees now enrolled in school. Some schools still managed to extract parental contributions, but a household expenditure survey suggested that this had fallen from more than half, to a quarter of primary school funding in $2000 .^{27}$

To compensate schools for the loss, the school supply capitation grant was rebranded as the UPE Capitation Grant, and its nominal value per student was doubled. ${ }^{28}$ The rough doubling of school population between 1995 and 2001 further doubled the overall value of the grant.

The surge in enrollment quickly overwhelmed the capacity of the Ugandan education system which turned to the World Bank for help. Over three years the Bank and other donors provided significant budget support and technical assistance toward UPE program. $^{29}$

Donors gave funding subject to conditions. One World Bank condition required Uganda to have "implemented a monitoring system for accountability on the use of public funds allocated to Districts and schools." 30 USAID also required that information on grants, salaries and finances be published on public notice boards at various official administrative locations within the district. Local schools were required to post information on enrollments, UPE capitation grants received, teachers salaries received and a copy of the school's quarterly report. Another condition was that three quarters of schools had received at least half of the non-wage allocation. ${ }^{31}$

The Ugandan government payed close attention to these conditions. The Ministry of Education and Sports conducted audits and commissioned reports on the flow of funds from disbursement through the entire system. ${ }^{32}$ These reports identified bottlenecks and delays in the flow of funds. ${ }^{33}$

Donors were satisfied that their conditions were met. According to USAID's assessment, about $90 \%$ of districts were displaying the details publicly, a similar proportion of schools were aware of their transparency obligations for capitation grants, and $90.4 \%$ of primary schools indicated that they had received at least $50 \%$ of their UPE capitation grant allocation. Publicity campaigns had been conducted not just in newspapers, but

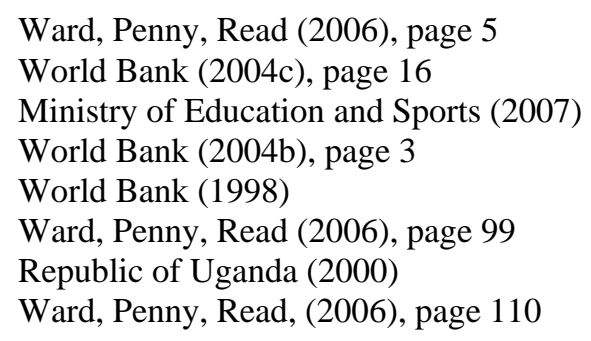


also on the radio. These campaigns provided much more than central government disbursements figures; they provided information about education budgets, emphasized accountability and urged parents to monitor school funding. ${ }^{34}$

The magnitude of the gains from the government's information policies are therefore obscured by the broader context of education and fiscal reform. Reinikka and Svennson's research demonstrates that information flows make a difference, but they cannot tell us the magnitude of the effect relative to these broader reforms. ${ }^{35}$

\section{Absolute versus proportional decreases in corruption}

The manner in which Reinikka and Svensson measure leakage, that is as a percentage of entitlement received, masks some of the real values. We saw earlier how UPE both increased the capitation grant amount, and resulted in massive growth of the school population, resulting in a much larger overall grant - about four times the value. Could it be that corruption was now taking a smaller slice of a larger pie?

When viewed as monetary amounts rather than percentage of entitlements, corruption did not fall so dramatically between 1995 and 2001. On this calculation, the nominal amount of funds that 'leaked' fell by a less spectacular $12 \%$ over 6 years, even after adjustment inflation. ${ }^{36}$ Of course, this real value would probably have risen significantly had the various accountability safeguards not been put in place. These figures should probably be considered when predicting how generally applicable the Ugandan results will be to other policy environments.

\section{Sustainability of the information effect}

There is some suggestive evidence that public interest and diligence in information postings had waned in the years after the initial information campaign. ${ }^{37}$ A World Bank evaluation also suggested that abolition of compulsory private fees had inadvertently

\footnotetext{
$34 \quad$ USAID/Uganda “CONDITIONALITIES 1997/98”

35 In a 2004 Transparency International report, Reinikka and Svensson suggested that "the information campaign can explain nearly 75 per cent of the reduction in capture of funds since the mid-1990s". This figure was based on an analysis of 'group effects' that included information sharing between school teachers, and uncertainty amongst district officials as to which schools were informed. This figure has not been repeated in later version of Reinikka and Svensson's research. In correspondence, Svensson indicated that the group effect is very difficult to identify and relies on a specific of assumptions with which they are now less comfortable.

$36 \quad$ Reinikka and Svensson (2004 at 685, 701) state that in practice the capitation grant from 19911995 was calculated based on the 1991 enrollment data with an average capitation of 3,177 U Sh per student. Based on the 1991 enrollment of 2.5 million students (Ministry of Finance and Planning, 2002, page 210), the overall capitation grant should have been approximately 8 billion U Sh. In 1995 schools received 21.9\% of their entitlement, so around 6 billion U Sh was diverted. In FY 2000/2001 the government released 38.9 billion U Sh for the UPE Capitation Grant according to Ministry of Education and Sports (2007). At this time schools then received $81.8 \%$ of their entitlement, meaning that about 7 billion U Sh (18.2\%) was diverted in 2001. This is a nominal increase in leakage by 800 million U Sh. This is a real fall of $12 \%$ when adjusted for Uganda's rapid inflation. 37

World Bank (2004a), page 17
} 
weakened incentives for parents to monitor school finances, as well as diminishing the power of the PTA to coordinate public action. ${ }^{38}$

An evaluation of the related School Facilities Grant found that "only in communities that were literate and assertive enough to act when abuse was revealed" were information disclosure the measures effective as an accountability mechanism. Those in particularly poor communities could be 'bought off' to discourage complaints. ${ }^{39}$ Furthermore, a report published in 2003 by the Royal Netherlands Embassy in Kampala noted that head teachers who enjoy high status in the community continued to misappropriate UPE funds, often in collaboration with district officials. ${ }^{40}$ While this is hardly evidence against government transparency, it suggests that transparency by itself is insufficient if there is no opportunity for collective action.

\section{Conclusion}

The Uganda case confirms that information does matter in reducing corruption, but the context suggests that it was about much more than the simple disclosure of information. Uganda's 'information disclosure' began with the government, not citizens, following the results of the first World Bank survey. This 'information' likely strengthened the resolve within the Government of Uganda for reform and also hardened the resolve of the donor community to reduce leakages. The information campaigns aimed at Uganda's citizens later became an element of this story, but was not the driving force.

In terms of the broader reduction in leakage of capitation funds between 1995 and 2001, information campaigns were probably a necessary, but not a sufficient condition of improvement. The restructuring of the grant from a block grant to a conditional grant should have had some effect on the application of funds for their specified purpose. Moreover, the introduction of universal primary education, with the contingent removal of parental fees, made the capitation grant a more important part of the funding mix. The UPE campaign also brought education funding to the public's attention.

Typical accounts of the Uganda story overlook this context. They attribute drop in the leakage rate to the central government's disclosure policy. Although this creates a good case study, it also runs the risk of inflating expectations on the returns to transparency policies. Clearly information is important, but the current evidence should not lead us to expect a similarly impressive reduction in rates of corruption will necessarily occur elsewhere this policy is implemented. 


\section{References}

Ablo, Emmanuel and Reinikka, Ritva, Do Budgets Really Matter? Evidence from Public Spending on Education and Health in Uganda (June 1998). World Bank Policy Research Working Paper No. 1926.

Bevan David L (2001), The Budget and Medium Term Expenditure Framework in Uganda Africa Region Working Paper Series No. 24, Washington DC: World Bank

Birdsall, Levine, Ibrahim, “Toward universal primary education: investments, incentives, and institutions" UN Millennium Project, Task Force on Education and Gender Equality, 2005, (http://www.unmillenniumproject.org/documents/Education-complete.pdf)

Brandeis, Louis (1914) Other People's Money and How Bankers Use it, New York: Friedrich A Stokes

Collier, Paul (2007) The Bottom Billion: Why the Poorest Countries Are Failing and What Can Be Done About It Oxford: Oxford University Press

Commonwealth Human Rights Initiative, Information Disclosure Policy: A Toolkit for Pacific Governments, 2006, http://www.pacmcf.com/PMCFinfo/pdf/full_report.pdf

Guild, Moulton, Wolf, DeStefmo and Wandira Support for Ugandan Primary Education Reform: A Formative Evaluation August 1995

Hallak, Jacques and Poisson, Muriel "Corrupt schools, corrupt universities: What can be done?” UNESCO / International Institute for Education Planning, 2007 (http://unpan1.un.org/intradoc/groups/public/documents/unesco/unpan025403.pdf)

Ministry of Education and Sports (1999), The Ugandan Experience of Universal Primary Education (UPE) Kampala

Ministry of Education and Sports (2001) Sixth Education Sector Review Final Aide Memoire, October 2001

http://www.usaid.or.ug/SO8Annexes/Aide\%20Memoire\%20Education\%20Sector\%20\%202001.doc

Ministry of Education and Sports (2007) UPE Allocation Formulae since inception, http://www.education.go.ug/UPEFormula.htm (last accessed 8 August 2007)

Ministry of Planning and Economic Development (1991) Background to the Budget 1991-1992, Kampala

Ministry of Planning and Economic Development (1992) Background to the Budget 1992-1993, Kampala 
Ministry of Planning and Economic Development (1996) Background to the Budget 1996-1997, Kampala

McIntosh Toby, Freedom of Information Laws Added to the Development Agenda, freedominfo.org 22 March 2006 (http://www.freedominfo.org/features/20060322.htm)

Reinikka, Ritva and Svensson, Jakob, (2001) Explaining Leakage of Public Funds (October 2001). World Bank Policy Research Working Paper No. 2709

Reinikka, Ritva, and Svensson, Jakob (2001b), Research Project Information and Voice in Public Spending,

http://siteresources.worldbank.org/DEC/Resources/PS.informationandvoiceproject.reinik ka.may1.pdf

Reinikka, Ritva, and Svensson, Jakob (2003) The Power of Information: Evidence from a Newspaper Campaign to Reduce Capture of Public Funds, European Development Research Network (EUDN) First Academic EUDN Conference: Economic Growth, Poverty Reduction, and Institutions, November 14-15, 2003, Paris, http://www.eudnet.net/workshops/afd_2003/svensson.pdf

Reinikka, Ritva and Svensson, Jakob (2004) "Local Capture: Evidence from a Central Government Transfer Program in Uganda” (May 2004) The Quarterly Journal of Economics 119:2, page 679-706

Reinikka, Ritva, and Svensson, Jakob (2006) The Power of Information: Evidence from a Newspaper Campaign to Reduce Capture of Public Funds, Institute for International Economic Studies, Stockholm University http://www.iies.su.se/ svenssoj/information2006a.pdf

Royal Netherlands Embassy (2003), Uganda: The Fight Against Corruption: A case study on the prevalence of corruption in Uganda, specifically in Local Government, Education, Justice, Law \& Order, and Procurement Commissioned by the Royal Netherlands Embassy Kampala, Uganda, December 2003 http://www.u4.no/document/showdoc.cfm?id=94

Stasavage, David "The role of democracy in Uganda's move to universal primary education” Journal of Modern African Studies, 43, 1 (2005), pp. 53-73

Transparency International (2004), Global Corruption Report

USAID (1991) Support for Ugandan Primary Education Reform Program Assistance Initial Proposal (617-0131), December 131991

USAID/Uganda “CONDITIONALITIES 1997/98” (Provided courtesy of USAID in Uganda) 
Ward, Penny, Read, Education Reform in Uganda - 1997 to 2004. Reflections on Policy, Partnership, Strategy and Implementation, Department for International Development, Researching the Issues 2006:60

World Bank (1993) Uganda: Social Sectors, Washington DC

World Bank (1998) Development Credit Agreement (Education Sector Adjustment Operation) between The Republic of Uganda and International Development Association, April 15, 1998

http://web.worldbank.org/external/projects/main?pagePK=64283627\&piPK=73230\&the $\underline{\text { SitePK }=40941 \& \text { menuPK=228424\&Projectid }=\mathrm{P} 002972}$

World Bank (2001) World Development Report 2000-01: Attacking Poverty, New York: Oxford University Press

World Bank (2004a) Project Performance Assessment Report Uganda, Primary Education and Teacher Development Project (Credit 2493), and Education Sector Adjustment Credit (Credit 3049), Washington DC January 8, 2004

World Bank (2004b), Uganda - Primary Education and Teacher Development and Education Sector Adjustment Adjustment Credit Project, 2004/01/08, http://wwwwds.worldbank.org/external/default/WDSContentServer/WDSP/IB/2004/01/20/00016001 6_20040120110828/Rendered/PDF/275380UG.pdf

World Bank (2004c), Achieving EFA in Uganda: the Big Bang approach, Washington DC, http://www1.worldbank.org/education/pdf/efa.case_uganda.pdf 